\title{
EFFET OF PLANT SPACING AND DEPTH OF USG PLACEMENT ON YIELD OF BORO RICE
}

\author{
S. Das ${ }^{1}$, A. K. Chaki ${ }^{2}$, N. Sobhan ${ }^{1}$, M. M. Hossain ${ }^{3}$ and H. M. Arshad ${ }^{4}$ \\ ${ }^{1}$ Scientific Officer, Soil Science Division, Bangladesh Institute of Nuclear Agriculture, Mymensingh \\ ${ }^{2}$ Scientific Officer, On-Farm Research Division, Bangladesh Agricultural Research Institute, Gazipur \\ ${ }^{3}$ Assistant Manager, Category and Procurement, ACI Limited, Dhaka \\ ${ }^{4}$ Assistant Director, Farm Division, BADC, Dattanagar, Jhenaidah \\ Corresponding author: dasshilpi84@yahoo.com
}

The farmers have to produce maximum rice from minimum land by adopting improved agronomic practices. Spacing of transplanting and depth of placement of urea super granules (USG) can play a significant role in increasing yield of rice. The plant to plant and row to row distances determine the plant population per unit area. Plant spacing has a direct effect on the yield of rice. The tillering habit and production of spikelets and panicles plant ${ }^{-1}$ depends on the spacing of transplanting which is responsible for variation in yield of rice. The plant spacing influences the availability of sunlight, leaf area index (LAI), nutrient to the plant and also photosynthesis and respiration.

Nitrogen is an essential element which influences the vegetative growth, seed development, yield and quality of rice. The loss of nitrogen is a problem for rice cultivation in this country. Modified urea fertilizers like USG, sylph coated urea etc. are designed to control one or more types of nitrogen loss to which ordinary urea is commonly susceptible. The superiority of USG, a slow releasing nitrogenous fertilizer, over conventional form of urea providing a steady supply of available nitrogen throughout the growing period of the crop. It may be important to know the optimum depth of placement of urea supper granules on the growth, development and yield of Boro rice. An increase in the yield of Boro rice can be expected if appropriate combination of spacing and depth of placement of urea supper granules is used. The present study was, therefore, undertaken with the objectives to study the response of spacing of transplanting and depth of placement of urea super granules (USG) on the yield of Boro rice.

The experiment was conducted at the Agronomy Research Field, Bangladesh Agricultural University (BAU), Mymensingh in the Boro season during 2008-2009. It belongs to the non-calcareous dark grey flood plain soil under the agro-ecological region of the Old Brahmaputra Floodplain. The experimental field was medium high with moderate drained condition. The land was silty loam in texture having a soil $\mathrm{pH}$ 6.42, and moderate in organic matter content. The experiment was laid out in a two factor randomized complete block design (RCBD) with three replications. The experiment comprised of two spacing of transplanting viz; $20 \mathrm{~cm} \mathrm{x} 20 \mathrm{~cm}$ and $20 \mathrm{~cm} \mathrm{x} 25 \mathrm{~cm}$ and three depths of placement of urea super granules viz; $6 \mathrm{~cm}, 8 \mathrm{~cm}$ and $10 \mathrm{~cm}$. The sprouted seeds of BRRI dhan 29 were sown in the nursery bed on 02 December 2008. Phosphorus @ $120 \mathrm{~kg} \mathrm{ha}^{-1}$ as triple super phosphate, potassium @ $60 \mathrm{~kg} \mathrm{ha}^{-1}$ as muriate of potash, sulphur@40 kg ha $\mathrm{kg}^{-1}$ as gypsum and zinc@10 $\mathrm{kg} \mathrm{ha}^{-1}$ as zinc sulphate were applied as a blanket dose in all the plots. A $2.7 \mathrm{~g}$ urea supper granule was applied at depths of $6 \mathrm{~cm}, 8 \mathrm{~cm}$ and $10 \mathrm{~cm}$ at the centre of four hills of two adjacent rows at 10 days after transplanting (DAT). Thirty five days old seedlings were transplanted on the well puddled experimental plots on 06 January 2009. The collected data were compiled and tabulated for statistical analysis and means were adjudged by Duncans Multiple Range Test (Gomez and Gomez, 1984).

Number of effective tillers hill ${ }^{-1}$, number of grains panicle ${ }^{-1}$, grain yield and straw yield of Boro rice was significantly influenced by spacing of transplanting (Table 1). The higher number of effective tillers hill ${ }^{-1}$ (13.37) was obtained from $20 \mathrm{~cm}$ x $25 \mathrm{~cm}$ spacing than (12.87) $20 \mathrm{~cm} \times 20 \mathrm{~cm}$. The result revealed that $20 \mathrm{~cm}$ x $25 \mathrm{~cm}$ spacing of transplanting had the greatest opportunity to produce more number of effective tillers hill ${ }^{-1}$. It might be due to the fact that wider spacing of transplanting provided enough nutrients, light and air which played vital role in producing more effective tillers hill ${ }^{-1}$. The results are in agreement with the findings of Haque (2002). The higher number of grains panicle ${ }^{-1}$ (115.84) was obtained from $20 \mathrm{~cm} \mathrm{x}$ 
Das et al.

$25 \mathrm{~cm}$ spacing of transplanting than from $20 \mathrm{~cm} \times 20 \mathrm{~cm}$ spacing of transplanting (114.74). This result was in agreement with that of Sarker et al. (2002). Depth of placement of urea super granules showed a significant response on all the yield and yield contributing characters except panicle length and weight of thousand grains (Table 2). The highest number of effective tillers hill ${ }^{-1}$ (16.39) was obtained from $8 \mathrm{~cm}$ depth of placement of USG and the lowest number (11.39)from $10 \mathrm{~cm}$ which followed by $6 \mathrm{~cm}$. The highest number of grains panicle $\mathrm{e}^{-1}$ (126.77) was found in $8 \mathrm{~cm}$ depth of placement of USG and the lowest (107.94) in $6 \mathrm{~cm}$. Continuous availability of nitrogen at $8 \mathrm{~cm}$ depth of placement of USG might enhance grain formation and development which eventually resulted in increased number of grains panicle ${ }^{-1}$. The highest grain yield $\left(5.08 \mathrm{t} \mathrm{ha}^{-1}\right)$ was found in $8 \mathrm{~cm}$ depth of placement of USG and the lowest one (3.73 t $\mathrm{ha}^{-1}$ in $6 \mathrm{~cm}$ depth. Eight centimeter depth of placement of USG produced the highest number of effective tillers hill ${ }^{-1}$ and number of grains panicle ${ }^{-1}$ and ultimately gave the highest grain yield. The highest straw yield $\left(6.18 \mathrm{t} \mathrm{ha}^{-1}\right)$ was obtained from $8 \mathrm{~cm}$ depth of placement of USG and the lowest (5.33 $\left.\mathrm{t} \mathrm{ha}^{-1}\right)$ from 6 cm depth. Similar trend was followed in harvest index.

Table 1. Response of plant spacing on different crop characters, yield components and yield of Boro rice

\begin{tabular}{c|c|c|c|c|c|c|c|c}
\hline $\begin{array}{c}\text { Spacing of } \\
\text { transplanting }\end{array}$ & $\begin{array}{c}\text { Plant } \\
\text { height } \\
(\mathrm{cm})\end{array}$ & $\begin{array}{c}\text { No. of } \\
\text { effective } \\
\text { tillers hill }\end{array}$ & $\begin{array}{c}\text { Panicle } \\
\text { length } \\
(\mathrm{cm})\end{array}$ & $\begin{array}{c}\text { No. of grains } \\
\text { panicle }^{-1}\end{array}$ & $\begin{array}{c}\text { Weight } \\
\text { of 1000- } \\
\text { grains } \\
(\mathrm{g})\end{array}$ & $\begin{array}{c}\text { Grain } \\
\text { yield } \\
\left(\mathrm{t} \mathrm{ha}^{-1}\right)\end{array}$ & $\begin{array}{c}\text { Straw } \\
\text { yield } \\
\left(\mathrm{t} \mathrm{ha}^{-1}\right)\end{array}$ & $\begin{array}{c}\text { Harvest } \\
\text { index } \\
(\%)\end{array}$ \\
\hline $\mathrm{S}_{1}$ & 96.45 & 12.87 & 21.92 & 114.74 & 21.75 & 4.46 & 5.70 & 43.63 \\
$\mathrm{~S}_{2}$ & 98.06 & 13.37 & 21.67 & 115.84 & 21.21 & 4.24 & 5.58 & 43.01 \\
$\mathrm{~S}\left(\frac{\mathrm{X}}{)}\right.$ & 0.42 & 0.18 & 0.20 & 0.61 & 0.12 & 0.04 & 0.04 & 0.28 \\
$\mathrm{CV}(\%)$ & 4.41 & 7.23 & 4.14 & 3.57 & 10.01 & 5.77 & 7.47 & 4.53 \\
\hline
\end{tabular}

Table 2. Response of depth of placement of urea super granules on different crop characters, yield components and yield of Boro rice

\begin{tabular}{|c|c|c|c|c|c|c|c|c|}
\hline $\begin{array}{l}\text { Depth } \\
\text { of USG } \\
4 \text { hills }^{-1}\end{array}$ & $\begin{array}{l}\text { Plant } \\
\text { height } \\
(\mathrm{cm})\end{array}$ & $\begin{array}{c}\text { No. of } \\
\text { effective } \\
\text { tillers hill }{ }^{-1}\end{array}$ & $\begin{array}{c}\text { Panicle } \\
\text { length } \\
(\mathrm{cm})\end{array}$ & $\begin{array}{c}\text { No. of } \\
\text { grains } \\
\text { panicle }^{-1}\end{array}$ & $\begin{array}{l}\text { Weight of } \\
1000 \\
\text { grains } \\
\text { (g) }\end{array}$ & $\begin{array}{c}\text { Grain } \\
\text { yield } \\
\left(\mathrm{t} \mathrm{ha}^{-1}\right)\end{array}$ & $\begin{array}{c}\text { Straw } \\
\text { yield } \\
\left(\mathrm{t} \mathrm{ha}^{-1}\right)\end{array}$ & $\begin{array}{c}\text { Harvest } \\
\text { index } \\
(\%)\end{array}$ \\
\hline $\mathrm{D}_{1}$ & $94.56 \mathrm{c}$ & $11.49 \mathrm{~b}$ & 21.43 & 107.94c & 21.54 & $3.73 c$ & $5.33 b$ & 41.01 \\
\hline $\mathrm{D}_{2}$ & $101.04 \mathrm{a}$ & $16.39 a$ & 21.98 & $126.77 a$ & 21.25 & $5.08 \mathrm{a}$ & $6.18 a$ & 45.13 \\
\hline $\mathrm{D}_{3}$ & $96.17 \mathrm{~b}$ & $11.39 \mathrm{~b}$ & 21.98 & 111.15b & 21.66 & $4.23 \mathrm{~b}$ & $5.41 b$ & 43.82 \\
\hline$S(\bar{X})$ & 0.52 & 0.22 & 0.25 & 0.75 & 0.14 & 0.04 & 0.05 & 0.34 \\
\hline CV (\%) & 4.41 & 7.23 & 4.14 & 1.68 & 10.01 & 3.57 & 7.47 & 4.53 \\
\hline
\end{tabular}

The effect of interaction of spacing of transplanting and depth of placement of urea super granules showed significant variation in respect of plant height, number of effective tillers hill ${ }^{-1}$, number of grains panicle $^{-1}$ and grain yield except panicle length, weight of thousand grains and straw yield (Table 3). The highest number of effective tillers hill $^{-1}(16.80)$ was obtained from $20 \mathrm{~cm} \mathrm{x} 25 \mathrm{~cm}$ spacing of transplanting x $8 \mathrm{~cm}$ depth of placement of USG and the lowest one (10.39) from $20 \mathrm{~cm} \mathrm{x} 25 \mathrm{~cm}$ spacing of transplanting of $6 \mathrm{~cm}$ depth. Similar trend was followed in case of no. of grains panicle ${ }^{-1}$.

From Table 3, it is evident that the highest grain yield $\left(5.30 \mathrm{t} \mathrm{ha}^{-1}\right)$ was obtained from $20 \mathrm{~cm} \mathrm{x} 20 \mathrm{~cm}$ spacing of transplanting $x 8 \mathrm{~cm}$ depth of placement of USG, while the lowest one $\left(3.68 \mathrm{t} \mathrm{ha}^{-1}\right)$ from $20 \mathrm{~cm}$ x $20 \mathrm{~cm}$. It is evident that the highest straw yield (5.82) was found in the interaction of $20 \mathrm{~cm} \mathrm{x} 25 \mathrm{~cm}$ spacing of transplanting and $2.7 \mathrm{~g}$ USG $\left(68 \mathrm{~kg} \mathrm{~N} \mathrm{ha}^{-1}\right)$ and the lowest $\left(5.16 \mathrm{t} \mathrm{ha}^{-1}\right) 20 \mathrm{~cm} \mathrm{x} 25 \mathrm{~cm}$ spacing of transplanting x $1.8 \mathrm{~g}$ USG (46 kg N ha-1). 
Spacing and USG Placement on Yield of Boro Rice

Table 3. Response of interaction of spacing of transplanting and depth of urea super granules placement on different crop characters, yield components and yield of Boro rice

\begin{tabular}{|c|c|c|c|c|c|c|c|c|}
\hline $\begin{array}{c}\text { Interaction } \\
(\mathrm{S} \times \mathrm{D})\end{array}$ & $\begin{array}{l}\text { Plant } \\
\text { height } \\
(\mathrm{cm})\end{array}$ & $\begin{array}{l}\text { No. of } \\
\text { effective } \\
\text { tillers } \\
\text { hill }^{-1}\end{array}$ & $\begin{array}{l}\text { Panicle } \\
\text { length } \\
(\mathrm{cm})\end{array}$ & $\begin{array}{c}\text { No. of } \\
\text { grains } \\
\text { panicle }^{-1}\end{array}$ & $\begin{array}{l}\text { Weight of } \\
1000 \\
\text { grains } \\
\text { (g) }\end{array}$ & $\begin{array}{c}\text { Grain } \\
\text { yield } \\
\left(\mathrm{t} \mathrm{ha}^{-1}\right)\end{array}$ & $\begin{array}{c}\text { Straw } \\
\text { yield } \\
\left(\mathrm{t} \mathrm{ha}^{-1}\right)\end{array}$ & $\begin{array}{c}\text { Harvest } \\
\text { index } \\
(\%)\end{array}$ \\
\hline $\mathrm{S}_{1} \times \mathrm{D}_{1}$ & 92.30c & $12.59 b$ & 21.23 & 105.82c & 21.61 & $3.68 \mathrm{e}$ & 5.32 & 40.67 \\
\hline $\mathrm{S}_{1} \times \mathrm{D}_{2}$ & $100.45 a$ & $15.97 a$ & 22.10 & $127.04 \mathrm{a}$ & 21.59 & $5.30 \mathrm{a}$ & 6.32 & 45.60 \\
\hline $\mathrm{S}_{1} \times \mathrm{D}_{3}$ & $96.59 b$ & $10.05 \mathrm{c}$ & 22.43 & $111.36 b$ & 22.06 & $4.40 \mathrm{c}$ & 5.45 & 44.63 \\
\hline $\mathrm{S}_{2} \times \mathrm{D}_{1}$ & $96.82 b$ & $10.39 c$ & 21.63 & 110.07b & 21.47 & $3.79 \mathrm{e}$ & 5.34 & 41.36 \\
\hline $\mathrm{S}_{2} \times \mathrm{D}_{2}$ & 101.63a & $16.80 a$ & 21.86 & $126.50 a$ & 20.91 & $4.86 \mathrm{~b}$ & 6.04 & 44.67 \\
\hline $\mathrm{S}_{2} \times \mathrm{D}_{3}$ & $95.74 \mathrm{~b}$ & $12.92 b$ & 21.53 & $110.95 b$ & 21.25 & $4.06 \mathrm{~d}$ & 5.36 & 43.01 \\
\hline $\mathrm{S} \overline{\mathrm{X}}$ & 0.73 & 0.32 & 0.35 & 1.06 & 0.20 & 0.06 & 0.07 & 0.48 \\
\hline CV (\%) & 4.41 & 5.14 & 4.14 & 3.57 & 10.01 & 5.77 & 7.47 & 4.53 \\
\hline
\end{tabular}

$\mathrm{S}_{1}=20 \mathrm{~cm} \times 20 \mathrm{~cm}, \mathrm{~S}_{2}=20 \mathrm{~cm} \times 25 \mathrm{~cm} \quad \mathrm{D}_{1}=6 \mathrm{~cm}, \mathrm{D}_{2}=8 \mathrm{~cm}, \mathrm{D}_{3}=10 \mathrm{~cm}$

In a column, figures with same letters or without letters do not differ significantly whereas figures with dissimilar letter differ significantly as per DMRT.

Based on the results of the study it can be concluded that the spacing of transplanting of $20 \mathrm{~cm} \mathrm{x} 20 \mathrm{~cm}$ in combination with $8 \mathrm{~cm}$ depth of placement of USG is the best for obtaining higher yield of Boro rice under the agro-ecological conditions of present study.

\section{References}

Gomez, K. A. and A. A. Gomez. 1984. Duncan's Multiple Range Test. Statistical Procedures for Agricultural Research. $2^{\text {nd }}$ Edn., A Wiley Inter-Science Publication, John Wiley and Sons, New York. pp.202-215.

Haque, D. E. 2002. Effect of Madagascar Technique of Younger seedling and Wider spacing on the Growth and Yield of Boro rice. M.S. Thesis, Dept. Agron., Bangladesh Agril. Univ., Mymensingh. pp.28-71.

Sarker, G., M. Rahman, R. Hasan and S. C. Roy. 2002. System of Rice Intensification: Yield and Economic Potential in Boro rice at different location of Bangladesh. LIFE-NOPEST-II Project, CARE, Bangladesh. pp.1-5. 